\title{
Generalized choreiform movements as a complication of methyldopa therapy in chronic renal failure
}

\author{
E. M. NEIL \\ B.Sc., M.B.
}

\author{
A. K. WATERS \\ M.A., M.B., B.Chir., M.R.C.P.
}

Wharfedale General Hospital, Otley, West Yorkshire

\begin{abstract}
Summary
A patient who developed bilateral choreiform movements in association with methyldopa therapy and deteriorating renal function without evidence of cerebrovascular disease is reported.
\end{abstract}

\section{Introduction}

Although methyldopa has been widely used in the treatment of hypertension for many years there is only a single case report (Yamadori and Albert, 1972) of bilateral choreoathetotic movements possibly related to treatment with this drug. That isolated case report was of a patient with concomitant severe bilateral cerebrovascular disease. The authors report here a similar case but in association with deteriorating renal function.

\section{Case report}

A 59-year-old Caucasian male was first seen in 1970 with maturity onset-type diabetes which was controlled by diet and chlorpropamide $250 \mathrm{mg}$ daily. In 1973, proteinuria was noted and blood urea was $11.8 \mathrm{mmol} / \mathrm{l}$. One year later, methyldopa $250 \mathrm{mg}$ thrice daily was commenced for hypertension (blood pressure $200 / 110 \mathrm{mmHg}$ ) with the subsequent addition of chlorthalidone. Renal function gradually deteriorated but the patient remained otherwise well. In August 1980, blood urea was $34.8 \mathrm{mmol} / \mathrm{l}$ and creatinine was $600 \mu \mathrm{mol} / 1$.

In October 1980, he was admitted with a 3-week history of involuntary jerking movements which had initially been worse in the evenings. The movements had gradually increased in severity until coarse jerking movements were present throughout the day being exacerbated by an attempt at voluntary movement. They disappeared completely during sleep. On examination, bilateral purposeless coarse twitching movements involving different muscle groups in the trunk, shoulder girdle and arms were observed.

There was no tremor, ataxia nor nystagmus.
Cranial nerves were intact and intellectual function was preserved. Power and tone were normal and symmetrically equal. Ankle reflexes were absent bilaterally but other tendon reflexes were normal and plantar responses were flexor. Sensation was intact apart from absent vibration sense below both knees. Chvostek's and Trousseau's signs were negative. BP was $160 / 90 \mathrm{mmHg}$ and he was anaemic. Investigations showed blood urea $44 \mathrm{mmol} / \mathrm{l}$, creatinine $963 \mu \mathrm{mol} / \mathrm{l}$, sodium $142 \mathrm{mmol} / \mathrm{l}$, potassium $4.4 \mathrm{mmol} / \mathrm{l}$, chloride $110 \mathrm{mmol} / \mathrm{l}$, bicarbonate $14 \mathrm{mmol} / 1$, creatinine clearance $4.8 \mathrm{ml} / \mathrm{min}$., calciung $1.54 \mathrm{mmol} / \mathrm{l}$, phosphate $3.23 \mathrm{mmol} / \mathrm{l}$, alkaline phosphatase 14 K.A.u./l, albumin $43 \mathrm{~g} / \mathrm{l}$, livé? function tests normal, $\mathrm{Hb} 8.6 \mathrm{~g} / \mathrm{dl}, \mathrm{MCH} 26.8 \mathrm{pg}$, MCV $85 \mathrm{fl}$, white cell count $7.9 \times 10^{9} / 1$, blood glucose $5 \mathrm{mmol} / \mathrm{l}$.

Methyldopa was discontinued $24 \mathrm{hr}$ after admission, and $12 \mathrm{hr}$ later the abnormal movements were diminishing in frequency and severity. After a further $24 \mathrm{hr}$ the abnormal movements had disappeared completely. All haematological and biochemical investigations were unchanged and he remained alert. A week later he developed oligura with rapidly rising blood urea and died. There had been no recurrence of his abnormal movements.

\section{Discussion}

The only previously reported case of involuntary movements associated with methyldopa therapy occurred in a patient with severe bilateral cerebrovascular disease after the dose had been increased from one $\mathrm{g}$ /day to $1.5 \mathrm{~g}$ /day (Yamadori and Albert, $N$ 1972). The case reported here is of interest in that the patient had no history or clinical evidence of $\widetilde{N}$ cerebrovascular disease and had been on the same $\omega$ dose of methyldopa for 7 years. The development of the abnormal movements coincided with deterioration in renal function.

As methyldopa is mainly excreted via the kidney, renal failure would be expected to lead to a rise in serum drug concentration. This increase may have 
been sufficient biochemically to trigger an abnormal movement pattern. In the presence of normal renal function a single oral dose of methyldopa produces a peak serum concentration after 3 to $6 \mathrm{hr}$ and $80-90 \%$ of the drug is eliminated after $48 \mathrm{hr}$ (Wade, 1977). In the absence of an alternative explanation, the disappearance of the abnormal movements within $36 \mathrm{hr}$ of stopping the methyldopa supports the implication of methyldopa in the aetiology of these movements.

\section{References}

WADE, A. (Ed.) (1977) Martindale.' The Extra Pharmacopoeia p. 667-669. The Pharmaceutical Press, London.

YAMADORI, A. \& AlBERT, M.L. (1972) Involuntary movement disorder caused by methyldopa. New England Journal of Medicine, 286, 620. 